\title{
PENGGUNAAN MULTIMEDIA PEMBELAJARAN INTERAKTIF DAN KREATIVITAS TERHADAP HASIL BELAJAR TEKNOLOGI INFORMASI DAN KOMUNIKASI (TIK)
}

\author{
Angel Susiana Sri Harningsih dan Efendi Napitupulu \\ SMA Negeri 1 Hamparan Perak Medan dan PPs Universitas Negeri Medan \\ angelsusi84@yahoo.com
}

\begin{abstract}
Abstrak: Penelitian ini bertujuan untuk mengetahui hasil belajar siswa yang diajar dengan penggunaan multimedia pembelajaran interaktif Macromedia Flash lebih tinggi daripada siswa yang diajar dengan penggunaan multimedia pembelajaran interaktif Power point dalam pembelajaran TIK, hasil belajar siswa yang memiliki kreativitas tinggi lebih baik daripada siswa yang memiliki kreativitas rendah dalam pembelajaran TIK, terdapat interaksi antara multimedia pembelajaran interaktif dengan kreativitas terhadap hasil belajar siswa dalam pembelajaran TIK. Metode penelitian menggunakan metode quasi eksperiment dengan desain penelitian faktorial $2 \times 2$, sedangkan teknik analisis data menggunakan ANAVA dua jalur pada taraf signifikansi $\alpha=0.05$. Hasil penelitian diperoleh bahwa hasil belajar TIK siswa yang dibelajarkan dengan menggunakan multimedia pembelajaran interaktif Macromedia Flash lebih tinggi daripada pembelajaran interaktif Power Point, Hasil belajar TIK siswa yang memiliki Kreativitas tinggi lebih tinggi daripada yang memiliki Kreativitas rendah, dan terdapat interaksi antara penggunaan multimedia dan Kreativitas dalam mempengaruhi hasil belajar TIK siswa.
\end{abstract}

Kata Kunci: multimedia interaktif model tutorial, multimedia interaktif model linier, kecerdasan visual-spasial, kecerdasan kinestetik

\begin{abstract}
This study aims to determine the learning outcomes of students who are taught with the use of multimedia interactive learning Macromedia Flash higher than students taught with the use of multimedia interactive learning power point in ICT learning, student learning outcomes that have high creativity better than students who have low creativity in ICT learning, there is interaction between multimedia interactive learning with creativity to the learning outcomes of students in ICT. Research method used quasi experiment with a $2 \times 2$ factorial study design, data analysis techniques while using ANOVA two lanes at the significance level $\alpha=0: 05$. The results showed that the ICT learning outcomes of students who learned with use of multimedia interactive learning higher than the Macromedia Flash interactive learning Power Point, ICT learning outcomes of students who have high creativity is higher than that having a low Creativity, and there was an interaction between the use of multimedia and creativity in ICT affects student learning outcomes.
\end{abstract}

Keywords: Interactive Multimedia of Tutorial Model, Interactive Multimedia of Linear Model, visual-spatial intelligence and kinesthetic intelligence

\section{PENDAHULUAN}

Berbagai indikasi menunjukkan bahwa mutu pendidikan belum meningkat secara signifikan, meskipun telah banyak upaya yang dilakukan oleh pemerintah, namun dalam kenyataannya mutu pendidikan masih tetap rendah. Rendahnya mutu pendidikan ini tercermin pada hasil belajar siswa yang salah satu tolak ukurnya adalah Ujian Akhir Nasional (UAS). Hal ini terjadi bahwa hasil belajar siswa rendah termasuk pada mata pelajaran TIK, yaitu nilainya berada dibawah nilai ketuntasan minimum (70). Data yang diperoleh dari kantor Tata Usaha, dapat dilihat bahwa nilai rata-rata UAS siswa kelas $\mathrm{X}$ untuk mata pelajaran TIK relatif rendah, menunjukkan bahwa nilai ratarata kurang memuaskan karena nilai yang diperoleh masih berada di bawah nilai cukup 7.0 data ini mengidentifikasikan bahwa hasil belajar Teknologi Informasi dan Komunikasi (TIK) masih rendah dan tidak berkembang sesuai dengan pertambahan waktu. 
Faktor rendahnya nilai siswa kelas $\mathrm{X}$ ini dimungkinkan karena banyak siswa kelas $\mathrm{X}$ mengalami (1) kesulitan dalam mempelajari konsep-konsep mata pelajaran TIK; (2) tidak familiar dengan istilah teknologi sehingga mengalami kesulitan dalam menggunakan teknologi; (3) keterbatasan guru dalam mendisain dan mengelolah serta menerapkan strategi pembelajaran ekspositori dan tidak menerapkan penggunaan Multimedia pembelajaran sehingga membuat siswa kurang tertarik dan kurang termotivasi dalam mempelajari TIK; (4) rendahnya kecerdasan emosional serta pengendalian diri siswa yang terlihat dari seringnya siswa tidak merawat sarana dan prasarana yang ada dan; (5) kurangnya motivasi, minat, pengendalian diri dan kreativitas siswa.

Upaya yang dapat dilakukan untuk meningkatkan mutu pendidikan yang sesuai dengan perkembangan IPTEKS di jaman era globalisasi ini adalah dengan adanya penggunaan Multimedia pembelajaran interaktif berbasis pada kemajuan TIK.

Ciri-ciri perkembangan IPTEK dalam era TIK yaitu; (1) daya muat untuk mengumpulkan, menyiapkan, memanipulasikan, dan menyajikan informasi meningkat; (2) kecepatan penyajian informasi meningkat; (3) miniaturisasi perangkat keras; (4) keragaman pilihan informasi; (5) menurunnya biaya perolehan informasi; (6) mudahnya penggunaan produk teknologi informasi; (7) distribusi informasi yang semakin cepat dan luas; (8) pemecahan masalah yang lebih baik dan dibuatnya prediksi masa depan yang lebih tepat (Miarso, 2004:664-665). Dalam era TIK seperti ini, kemampuan masyarakat dalam memanfaatkan pengetahuannya untuk meningkatkan produktivitas menjadi vital. Pendidikan seyogianya harus mampu membangun sumberdaya manusia yang seperti ini. Oleh karena itulah, kebijakan pendidikan perlu diarahkan agar mampu menyiapkan sumber daya manusia yang mampu menghadapi tantangan masa depan secara efektif dan efesien, dengan memanfaatkan seluruh aspek sumber daya yang ada termasuk pemanfaatan TIK.

Dengan memanfaatkan media, siswa yang dihadapkan pada obyek yang lebih nyata dan memberikan ransangan pada aktivitas daya indera secara bervariasi sehingga memungkinkan materi yang disajikan lebih mudah dipahami dan dipertahankan dalam ingatan. Pemanfaatan media dapat memberikan berbagai pengalaman yang memungkinkan keterlibatan aktif siswa dalam pembelajaran. Pemanfaatan media yang sesuai dengan karakteristik siswa dapat menumbuh kembangkan daya pikir dan kreativitas siswa serta memungkinkan terjadinya belajar sendiri. Pada akhirnya, pemanfaatan media memungkinkan tercapainya efektivitas pembelajaran mandiri dan meningkatkan hasil belajar TIK.

Kreativitas sebagai suatu potensi yang dimiliki oleh setiap siswa belum menjadi perhatian pendidik dalam upaya meningkatkan hasil belajar. Dengan kreativitas yang dimilikinya, siswa dapat meningkatkan pencapaian hasil belajarnya. Siswa yang kreatif dapat menunjukkan hasil belajar yang sama bahkan lebih dari siswa yang memiliki kecerdasan intelektual.

Pada umumnya, siswa yang memiliki kreativitas tinggi mempunyai keterkaitan terhadap TIK. Pelajaran TIK pada sebagian siswa dianggap kurang menarik dan menyenangkan, tetapi bagi siswa kreatif malah mengasyikkan karena menantang pemikiran kritis dan kreativitas mereka. Mereka dengan antusias terlibat aktif dalam pembelajaran untuk mencari tahu tentang cara pengoperasian komputer. Mereka tertantang untuk dapat mengoperasikan komputer sesuai dengan materi yang disajikan bahkan mereka mencoba untuk bereksperimen mengikuti imajinasi berpikirnya. Tetapi karena selama ini dalam pembelajaran TIK, guru kurang mendesain dan mengelolah serta kurang menerapkan penggunaan multimedia pembelajaran interaktif, membuat para siswa cepat bosan dan kurang berminat dalam mempelajari materi yang disampaikan.

Program multimedia interaktif yang dirancang untuk keperluan belajar siswa harus dilengkapi dengan tes sehingga siswa akan bisa mengukur sendiri pencapaian hasil belajarnya. Dengan sajian yang interaktif, melalui program multimedia siswa akan dapat belajar dengan bantuan seminimal mungkin dari guru atau orang lain dan belajar sesuai dengan kecepatan belajar masing-masing (Self-pacing), baik bagi slow-learner maupun fast-learner.

Untuk melibatkan siswa lebih aktif dalam belajar, peneliti ingin mengetahui efektivitas penggunaan multimedia pembelajaran interaktif dalam mata pelajaran TIK. Multimedia interaktif dalam penelitian 
ini adalah multimedia interaktif macromedia flash MX dan Power point. Dengan penggunaan Multimedia interaktif yang penekanannya pada proses pengkombinasian dari berbagai media yang dikemas (diprogram) secara terpadu dan interaktif untuk penyajian pesan pembelajaran tertentu, diharapkan mampu memperbaiki hasil belajar siswa dalam pelajaran TIK.

Smaldino et al. (2005:148) menjabarkan media interaktif berbasis komputer menciptakan pembelajaran multimedia yang menggabungkan antara video dan computer-assisted instruction. Hal tersebut merupakan sistem penyampaian pembelajaran berupa rekaman visual, suara dan bahan-bahan berupa video yang diperkenalkan diabwah kendali komputer dan bukan hanya dapat dilihat dan didengar, tetapi siswa juga dapat memberi tanggapan (active response) dengan demikian tanggapan atau interaksi siswa mempengaruhi urutan penyajian materi (sequence of the presentation). Sedangkan menurut Heinich (1985) penggunaan istilah multimedia berbasis komputer sebagai penggabungan teknologi komputer dengan berbagai sumber materi baik dalam bentuk teks, gambar, grafik, dan suara yang ditampilkan melalui layar komputer.

Macromedia Flash yang merupakan suatu software yang banyak dipakai oleh desainer web karena mempunyai kemampuan yang lebih unggul dalam menampilkan multimedia, gabungan antara grafis, animasi, suara, serta interaktifitas user (Didik, 2003). Macromedia Flash merupakan sebuah program aplikasi standar authoring tool profesional yang digunakan untuk membuat animasi vektor dan bitmap yang sangat menakjubkan untuk membuat suatu situs interaktif, menarik dan dinamis (Andreas, 2003). Software ini berbasis animasi vektor yang dapat digunakan untuk menghasilkan animasi web, presentasi, game, film maupun CD interaktif, dan CD pembelajaran. Program ini juga dapat diisi dengan bitmap yang diimpor dari program lain.

Multimedia interaktif adalah bila suatu aplikasi terdapat di seluruh elemen multimedia yang ada dan pemakai (user) diberi kebebasan/ kemampuan untuk mengontrol dan menghidupkan elemenelemen tersebut. Senada dengan hal tersebut Warsita (2008) mendefenisikan multimedia interaktif sebagai kombinasi dari berbagai media yang dikemas (diprogram) secara terpadu dan interaktif untuk menyajikan pesan pembelajaran tersebut.

Menurut Widada (2010) Multimedia interaktif Power point merupakan salah satu program Multimedia audio visual yang berbentuk aplikasi dari program komputer, yang digunakan sebagai alat bantu untuk memaparkan atau mempresentasikan sebuah materi tertentu. Aplikasi ini biasa dipakai oleh dunia bisnis, akademis, pelatihan dan lainnya. Power point merupakan sebuah software yang dibuat dan dikembangkan oleh perusahaan microsoft, dan merupakan salah satu program berbasis Multimedia. Didalam komputer, biasanya program ini sudah dikelompokkan dalam program microsoft office. Program ini dirancang khusus untuk menyampaikan presentasi, baik yang diselenggarakan oleh perusahaan, pemerintah, pendidikan maupun perorangan dengan berbagai fitur menu yang mampu menjadikannya sebagai Multimedia komunikasi yang menarik.

Utami Munandar

mengatakan bahwa kreativitas adalah hasil dari interaksi antar individu dan lingkungannya. Seseorang mempengaruhi dan dipengaruhi oleh lingkungan dimana ia berada, dengan demikian baik perubah di dalam individu maupun didalam lingkungan dapat menunjang atau dapat menghambat upaya kreatif. Implikasinya adalah bahwa kemampuan kreatif dapat ditingkatkan melalui pendidikan.

Supriadi (1999) mengatakan bahwa krativitas merupakan bidang kajian yang dapat menimbulkan berbagai pandangan yang berbeda. Perbedaan ini terletak pada defenisi kreativitas, kriteria perilaku, proses kreatif, hubungan kreativitas dengan intelegensi, karakteristik orang kreatif dan upaya untuk menggabungkan kreativitas

Woolfolk (2009:90) mendefenisikan kreativitas adalah kemampuan untuk menghasilkan karya yang orisinal, tetapi tepat guna dan bermanfaat. Selanjutnya Woolfolk menjelaskan sumber kreativitas ada 3 yaitu: (1) keterampilan relevan-termasuk berbagai talenta dan kompetensi yang bermanfaat untuk bekerja di ranah tersebut, (2) prosesproses relevan-kreativitas termasuk berbagai kebiasaan kerja dan ciri kepribadian, dan (3) motivasi tugas intrinsik atau keingintahuan atau keterpesonaan yang mendalam terhadap tugas. Rhodes (Munandar, 2009) menyimpulkan bahwa pada umumnya 
kreativitas dirumuskan dalam istilah pribadi (person), proses dan produk. Kreativitas dapat pula ditinjau dari kondisi pribadi dan lingkungan yang mendorong (press) individu ke prilaku aktif.

Kreativitas sebagai suatu proses, pada prinsipnya hampir sama dengan langkah metode ilmiah, menurut Torrance (1974) meliputi proses merasakan adanya permasalahan, kesenjangan informasi, ketidaklengkapan unsur dan sesuatu yang ditanyakan, proses membuat terkaan dan merumuskan hipotesis, proses mengevaluasi dan menguji hipotesis, proses meninjau ulang dan menguji kembali, serta akhirnya mengkomunikasikan kesimpulan yang diperoleh.

Selanjutnya, menurut Wallas seperti yang dikutip oleh Munandar (2009:39) menyatakan bahwa proses kreatif berlangsung melalui empat tahap, yaitu persiapan (preparation), inkubasi (incubation), iluminasi (illumination) dan verifikasi (verification). Tahapan persiapan adalah tahap identifikasi dan pengumpulan informasi untuk memecahkan permasalahan. Pada tahap inkubasi proses pemecahan masalah direnungkan sampai timbul inspirasi atau gagasan untuk memecahkan masalah. Tahap iluminasi, gagasan dimunculkan dalam langkah konkrit pemecahan masalah. Sedangkan tahap verifikasi, gagasan dan strategi pemecahan masalah dievaluasi secara kritis dan dihadapkan pada realita.

Berdasarkan berbagai defenisi teori kreativitas di atas, maka dapat ditarik beberapa kesimpulan yaitu: (a) jika dipandang dari sudut psikologis, kreativitas merupakan kemampuan yang dimiliki oleh setiap orang dengan tingkat berbeda-beda sebagai ekspresi tertinggi keberbakatannya dan terintegrasi dari semua fungsi dasar manusia dalam berfikir, merasa, mengindera, dan intuisi. (b) dipandang dari sudut interaksi sosial, kreativitas merupakan hasil serangkaian proses interaksi sosial antara keunikan individu dengan lingkungannya. (c) dipandang dari segi penekanan konsep dalam menentukan kriteria, kreativitas dibedakan dalam dimensi person (person), proses (process), produk (product), dan dorongan (press), serta penilaiannya sangat bergantung pada konteks sosial, budaya dan waktu. (d) pada intinya kreativitas merupakan kemampuan seseorang untuk menghasilkan sesuatu yang baru dan bermanfaat, baik berupa gagasan atau karya nyata yang realtif berbeda dengan sesuatu yang telah ada sebelumnya, maupun kemampuan untuk menemukan banyak kemungkinan jawaban dengan cara-caranya sendiri terhadap suatu masalah yang dihadapi.

Penelitian ini bertujuan untuk mengetahui: (1) Hasil belajar siswa yang diajar dengan penggunaan multimedia pembelajaran interaktif Macromedia Flash lebih tinggi daripada siswa yang diajar dengan penggunaan multimedia pembelajaran interaktif Power point dalam pembelajaran TIK; (2) Hasil belajar siswa yang memiliki kreativitas tinggi lebih baik daripada siswa yang memiliki kreativitas rendah dalam pembelajaran TIK; (3) Terdapat interaksi antara multimedia pembelajaran interaktif dengan kreativitas terhadap hasil belajar siswa dalam pembelajaran TIK.

\section{METODE PENELITIAN}

Penelitian dilaksanakan di SMA Negeri 1 Hamparan Perak di kelas X semester 2, Populasi dalam penelitian ini adalah seluruh siswa kelas $\mathrm{X}$, yang terdiri dari 6 (enam) kelas, Dari keseluruhan populasi maka yang dijadikan sampel adalah 2 (kelas) yang diambil secara cluster random sampling.

Penelitian ini menggunakan metode eksperimen dengan rancangan quasi eksperimen desain faktorial $2 \times 2$. Melalui desain ini akan dibandingkan pengaruh penggunaan multimedia pembelajaran interaktif Macromedia Flash dan pembelajaran dengan menggunakan multimedia pembelajaran Power Point. Kreativitas siswa dibedakan atas kreativitas tinggi dan kreativitas rendah. Penggunaan multimedia interaktif pembelajaran sebagai variabel bebas, Kreativitas sebagai variabel moderator dan hasil belajar TIK sebagai variabel terikat.

Teknik analisis data yang digunakan adalah Teknik Statistik Deskriptif dan Inferensial. Teknik statistik deskriptif digunakan untuk mendeskriptifkan data, antara lain: nilai rata-rata (mean), median, modus, standard deviasi (sd), variansi dan kecenderungan data. Teknik statistik inferensial digunakan untuk menguji hipotesis penelitian, dimana teknik inferensial yang digunakan adalah teknik analisis varians (ANAVA) dua jalur (desain faktorial 2x2) dan uji statistik yang digunakan adalah uji $\mathrm{F}$ dengan $\alpha=0,05$. 
Sebelum menggunakan teknik ini, lebih dahulu ditentukan persyaratan analisis yakni persyaratan Normalitas dan Homogenitas. Untuk uji persyaratan Normalitas menggunakan uji Liliefors, sedangkan untuk uji persyaratan Homogenitas menggunakan uji Barlett. Dari hasil analisis data, apabila terdapat perbedaan penggunaan multimedia pembelajaran interaktif dan interaksi antara penggunaan multimedia pembelajaran interaktif dan kreativitas terhadap hasil belajar signifikan, maka dilakukan uji lanjut untuk melihat kelompok mana yang lebih signifikan perbedaannya.

\section{HASIL DAN PEMBAHASAN \\ Hasil}

Setelah dilakukan pengujian kedua persyaratan analisis yakni uji normalitas dan uji homogenitas, maka dapat dipastikan bahwa persyaratan yang harus dipenuhi oleh data penelitian dalam rangka penggunaan teknik analisis varians (ANAVA) telah dipenuhi, maka teknik analisis tersebut telah dapat digunakan.

Pengujian hipotesis dilakukan menggunakan teknik analisis varians (ANAVA). Untuk keperluaan analisis varians, data yang diperlukan dapat dilihat pada Tabel 1.

Tabel 1. Data Hasil Belajar TIK Siswa

\begin{tabular}{|c|c|c|c|}
\hline \multirow[b]{2}{*}{$\begin{array}{l}\text { Kreatifitas } \\
\text { (B) }\end{array}$} & \multicolumn{2}{|c|}{ Multimedia Pembelajaran Interaktif (A) } & \multirow[t]{2}{*}{ Total } \\
\hline & $\begin{array}{c}\text { Pembelajaran Interaktif } \\
\text { Macromedia Flash } \\
\left(\mathrm{A}_{1}\right)\end{array}$ & $\begin{array}{l}\text { Pembelajaran Interaktif } \\
\text { Power Point }\left(\mathrm{A}_{2}\right)\end{array}$ & \\
\hline \multirow{5}{*}{$\begin{array}{c}\text { K Tinggi } \\
\left(B_{1}\right)\end{array}$} & $\mathrm{n}_{\mathrm{A} 1 \mathrm{~B} 1}=18$ & $\mathrm{n}_{\mathrm{A} 2 \mathrm{~B} 1}=16$ & $\mathrm{~N}_{\mathrm{KT}}=34$ \\
\hline & $\bar{x}_{\mathrm{A} 1 \mathrm{~B} 1}=30,77$ & $\bar{x}_{\mathrm{A} 2 \mathrm{~B} 1}=25,75$ & $\bar{X}_{\mathrm{KT}}=3,7$ \\
\hline & $\mathrm{SD}=2,90$ & $\mathrm{SD}=2,51$ & $\mathrm{SD}=5,26$ \\
\hline & $=554$ & $\sum x=412$ & $\sum x=966$ \\
\hline & $\Sigma x^{2}=17194$ & $\Sigma x^{2}=10704$ & $\Sigma x^{2}=17898$ \\
\hline \multirow{5}{*}{$\begin{array}{l}\text { K Rendah } \\
\quad\left(B_{2}\right)\end{array}$} & $\mathrm{n}_{\mathrm{A} 1 \mathrm{~B} 2}=14$ & $\mathrm{n}_{\mathrm{A} 2 \mathrm{~B} 2}=15$ & $\mathrm{~N}_{\mathrm{KR}}=29$ \\
\hline & $\bar{x}_{\mathrm{A} 1 \mathrm{~B} 2}=25,64$ & $\bar{x}_{\mathrm{A} 2 \mathrm{~B} 2}=28,4$ & $\bar{X}_{\mathrm{KR}}=27,02$ \\
\hline & $\mathrm{SD}=2,37$ & $\mathrm{SD}=2,74$ & $\mathrm{SD}=2,89$ \\
\hline & $\sum x=359$ & $\sum x=426$ & $\sum x=785$ \\
\hline & $\Sigma x^{2}=9279$ & $\Sigma x^{2}=12204$ & $\Sigma x^{2}=21483$ \\
\hline \multirow{5}{*}{ Total } & $\mathrm{N}_{\mathrm{MF}}=32$ & $\mathrm{~N}_{\mathrm{PP}}=31$ & $\mathrm{n}_{\mathrm{tot}}=63$ \\
\hline & $\bar{X}=28,21$ & $\bar{X}=27,08$ & $\bar{X}_{\text {tot }}=27,64$ \\
\hline & $\mathrm{SD}=3,69$ & $\mathrm{SD}=2,91$ & $\mathrm{SD}=3,30$ \\
\hline & $\sum x=913$ & $\sum x=838$ & $\sum x=1751$ \\
\hline & $\Sigma x^{2}=26473$ & $\Sigma x^{2}=22908$ & $\sum x^{2}=49381$ \\
\hline
\end{tabular}

Hasil perhitungan ANAVA seperti yang ditunjukkan dalam Tabel 2, yaitu rangkuman analisis faktorial $2 \times 2$.

Tabel 2. Rangkuman Analisis Faktorial 2x2

\begin{tabular}{|l|r|c|r|c|c|c|}
\hline \multicolumn{1}{|c|}{ Sumber Varians } & \multicolumn{1}{c|}{ JK } & dk & \multicolumn{1}{c|}{ RJK } & $\mathrm{F}_{\text {hitung }}$ & $\mathrm{F}_{\text {tabel }}$ & Kesimpulan \\
\hline Multimedia & & & & & & \\
Pembelajaran & 35.381 & 1 & 35.381 & 5.007 & 3,96 & Signifikan \\
Kreatifitas & 28.22 & 1 & 28.2201 & 14.03 & 3,96 & Signifikan \\
Interaksi & 233.79 & 1 & 233.791 & 33.08 & 3,96 & Signifikan \\
\hline Antar kelompok & 297.39 & 3 & 99.1307 & - & & \\
Dalam kelompok & 416.93 & 56 & 7.06653 & & & \\
\hline Total & 714.32 & 62 & & & & \\
\hline
\end{tabular}


Berdasarkan rangkuman di atas maka akan dirinci pengujian hipotesis sebagai berikut:

Pengujian hipotesis pertama yang menyatakan hasil belajar TIK siswa yang dibelajarkan dengan multimedia pembelajaran interaktif macromedia flash, lebih tinggi daripada hasil belajar siswa yang diajarkan dengan multimedia pembelajaran interaktif power point, Hipotesis statistiknya adalah:

Ho: $\mu_{\mathrm{A} 1} \leq \mu_{\mathrm{A} 2} \quad$ Ha $: \mu_{\mathrm{A} 1}>\mu_{\mathrm{A} 2}$

Pernyataan hipotesis tersebut adalah:

Ho = Tidak terdapat perbedaan hasil belajar TIK antara siswa yang dibelajarkan dengan menggunakan multimedia pembelajaran interaktif macromedia flash dengan siswa yang dibelajarkan dengan multimedia pembelajaran interaktif power point.

$\mathrm{Ha}=$ Siswa yang dibelajarkan dengan menggunakan multimedia pembelajaran interaktif macromedia flash memperoleh hasil belajar TIK lebih tinggi daripada siswa yang dibelajarkan dengan multimedia pembelajaran interaktif power point

Berdasarkan perhitungan ANAVA faktorial $2 \times 2$ diperoleh $F_{\text {hitung }}=5,007$ sedangkan nilai $\mathrm{F}_{\text {tabel }}=3,96$ untuk $\mathrm{dk}(1,56)$ dan taraf nyata $\alpha=0,05$. Ternyata nilai $F_{\text {hitung }}$ $=5,149>\mathrm{F}_{\text {tabel }}=3,96$ sehingga pengujian hipotesis menolak Ho. Dengan demikian dapat ditarik kesimpulan bahwa hasil belajar TIK siswa yang dibelajarkan dengan Multimedia Pembelajaran Interaktif Macromedia Flash lebih tinggi dibanding dengan Multimedia Pembelajaran Interaktif Power Point dapat diterima dan terbukti secara empirik. Hal ini juga terlihat dari ratarata hasil belajar TIK yang dibelajarkan dengan Multimedia Pembelajaran Interaktif Macromedia Flash $(\bar{x}=28,21)$ lebih tinggi dari hasil belajar TIK yang dibelajarkan dengan multimedia Power Point ( $\bar{x}=27,06)$.

Pengujian hipotesis kedua yang menyatakan: siswa yang memiliki kreatifitas tinggi memiliki hasil belajar TIK, lebih tinggi daripada hasil belajar siswa yang memiliki kreatifitas rendah, Hipotesis statistiknya adalah:

Ho : $\mu_{\mathrm{B} 1} \leq \mu_{\mathrm{B} 2} \quad$ Ha $: \mu_{\mathrm{B} 1}>\mu_{\mathrm{B} 2}$

Pernyataan hipotesis tersebut adalah :

Ho = Tidak terdapat perbedaan hasil belajar TIK antara siswa yang memiliki kreatifitas tinggi dengan siswa yang memiliki kreatifitas rendah

Ho $=$ Siswa yang memiliki kreatifitas tinggi memperoleh hasil belajar TIK lebih tinggi daripada siswa yang memiliki kreatifitas rendah

Berdasarkan perhitungan ANAVA faktorial $2 \times 2$ diperoleh $F_{\text {hitung }}=14,03$ sedangkan nilai $\mathrm{F}_{\text {tabel }}=3,96$ untuk dk $(1,56)$ dan taraf nyata $\alpha=0,05$. Ternyata nilai $F_{\text {hitung }}$ $=14,03>\mathrm{F}_{\text {tabel }}$ sehingga pengujian hipotesis menolak Ho. Dengan demikian dapat ditarik kesimpulan bahwa hasil belajar TIK siswa yang memiliki kreatifitas tinggi lebih tinggi dibanding siswa yang memiliki kreatifitas rendah dapat diterima dan terbukti secara empirik. Hal ini juga terlihat dari rata-rata hasil belajar TIK yang dibelajarkan dengan multimedia pembelajaran interaktif macromedia flash $(\bar{x}=28,26)$ lebih tinggi dari hasil belajar TIK yang dibelajarkan dengan multimedia pembelajaran interaktif power point $(\bar{x}=27,02$.

Pengujian hipotesis yang ketiga yaitu: terdapat interaksi antara multimedia pembelajaran interaktif dan kreatifitas dalam meningkatkan hasil belajar TIK.

Ho: A X B $=0 \quad$ Ha : A X B $\neq 0$

Pernyataan hipotesis tersebut adalah:

$\mathrm{Ho}=$ Tidak terdapat interaksi antara multimedia pembelajaran interaktif dan kreatifitas terhadap hasil belajar TIK siswa.

Ho = Terdapat terdapat interaksi antara multimedia pembelajaran interaktif dan kreatifitas terhadapa hasil belajar TIK siswa.

Berdasarkan perhitungan ANAVA faktorial $2 \times 2$ diperoleh $\mathrm{F}_{\text {hitung }}=33,08$ sedangkan nilai $\mathrm{F}_{\text {tabel }}=3,96$ untuk $\mathrm{dk}(1,56)$ dan taraf nyata $\alpha=0,05$. Ternyata nilai $F_{\text {hitung }}$ $=33,08>\mathrm{F}_{\text {tabel }}$ sehingga pengujian hipotesis menolak Ho. Dengan demikian dapat ditarik kesimpulan bahwa terdapat interaksi antara multimedia pembelajaran interaktif dan kreatifitas dalam meningkatkan hasil belajar TIK siswa dapat diterima dan terbukti secara empirik.

Untuk mengetahui interaksi antara multimedia pembelajaran interaktif dan kreatifitas terhadap hasil belajar TIK, maka dilakukan uji lanjut dengan Uji Scheffe. 
Tabel 3. Rangkuman Uji Scheffe

\begin{tabular}{|l|l|c|c|}
\hline \multicolumn{2}{|c|}{ Hipotesis Statistik } & $\mathbf{F}_{\text {hitung }}$ & $\begin{array}{c}\mathbf{F}_{\text {tabel }}(\mathbf{3 , 5 6}) \\
\boldsymbol{\alpha}=\mathbf{0 , 0 5}\end{array}$ \\
\hline Ho: $\mu_{\mathrm{A} 1 \mathrm{~B} 1}=\mu_{\mathrm{A} 2 \mathrm{~B} 1}$ & Ha: $\mu_{\mathrm{A} 1 \mathrm{~B} 1}>\mu_{\mathrm{A} 2 \mathrm{~B} 1}$ & 6.03 & 2,73 \\
\hline Ho: $\mu_{\mathrm{A} 1 \mathrm{~B} 1}=\mu_{\mathrm{A} 1 \mathrm{~B} 2}$ & Ha: $\mu_{\mathrm{A} 1 \mathrm{~B} 1}>\mu_{\mathrm{A} 1 \mathrm{~B} 2}$ & 5.72 & 2,73 \\
\hline Ho: $\mu_{\mathrm{A} 1 \mathrm{~B} 1}=\mu_{\mathrm{A} 2 \mathrm{~B} 2}$ & Ha: $\mu_{\mathrm{A} 1 \mathrm{~B} 1}>\mu_{\mathrm{A} 2 \mathrm{~B} 2}$ & 2.75 & 2,73 \\
\hline Ho: $\mu_{\mathrm{A} 2 \mathrm{~B} 1}=\mu_{\mathrm{A} 1 \mathrm{~B} 2}$ & Ha: $\mu_{\mathrm{A} 2 \mathrm{~B} 1}<\mu_{\mathrm{A} 1 \mathrm{~B} 2}$ & 0.11 & 2,73 \\
\hline Ho: $\mu_{\mathrm{A} 2 \mathrm{~B} 1}=\mu_{\mathrm{A} 2 \mathrm{~B} 2}$ & Ha: $\mu_{\mathrm{A} 2 \mathrm{~B} 1}<\mu_{\mathrm{A} 2 \mathrm{~B} 2}$ & 2.9 & 2,73 \\
\hline Ho: $\mu_{\mathrm{A} 2 \mathrm{~B} 2}=\mu_{\mathrm{A} 1 \mathrm{~B} 2}$ & Ha: $\mu_{\mathrm{A} 2 \mathrm{~B} 2}>\mu_{\mathrm{A} 1 \mathrm{~B} 2}$ & 2.83 & 2,73 \\
\hline
\end{tabular}

Berdasarkan Tabel 3 di atas terdapat satu dari enam kombinasi yang dibandingkan menunjukkan hasil yang tidak signifikan, hal ini disebabkan oleh tidak terdapatnya perberdaan yang signifikan antara rata-rata hasil belajar TIK yang dibelajarkan dengan menggunakan multimedia pembelajaran interaktif power point berdasarkan kreatifitas tinggi dan rata-rata hasil belajar TIK yang dibelajarkan dengan multimedia pembelajaran interaktif macromedia flash berdasarkan kreatifitas tinggi.

Dari hasil uji Scheffe di atas diperoleh simpulan: (1) Rata-rata hasil belajar TIK siswa yang dibelajarkan dengan multimedia pembelajaran interaktif macromedia flash berdasarkan kreatifitas tinggi lebih tinggi dibandingkan dengan rata-rata hasil belajar TIK siswa yang dibelajarkan dengan multimedia pembelajaran interaktif power point berdasarkan kreatifitas tinggi. (2) Ratarata hasil belajar TIK siswa yang dibelajarkan dengan multimedia pembelajaran interaktif macromedia flash berdasarkan kreatifitas tinggi lebih tinggi dibanding dengan rata-rata hasil belajar TIK siswa dengan multimedia pembelajaran interaktif macromedia flash berdasarkan kreatifitas rendah. (3) Rata-rata hasil belajar TIK siswa yang dibelajarkan dengan multimedia pembelajaran interaktif macromedia flash berdasarkan kreatifitas tinggi lebih tinggi dibandingkan dengan ratarata hasil belajar TIK siswa yang dibelajarkan dengan multimedia pembelajaran interaktif power point dan kreatifitas rendah. (4) Ratarata hasil belajar TIK siswa yang dibelajarkan dengan multimedia pembelajaran interaktif power point berdasarkan kreatifitas tinggi lebih rendah dibanding dengan rata-rata hasil belajar TIK siswa yang dibelajarkan dengan multimedia pembelajaran interaktif macromedia flash berdasarkan kreatifitas rendah. (5) Rata-rata hasil belajar TIK siswa yang dibelajarkan dengan multimedia pembelajaran interaktif power point berdasarkan kreatifitas tinggi lebih rendah dibandingkan dengan rata-rata hasil belajar TIK siswa yang dibelajarkan dengan multimedia pembelajaran interaktif power point berdasarkan kreatifitasrendah. (6) Ratarata hasil belajar TIK siswa dengan multimedia pembelajaran pembelajaran interaktif power point berdasarkan kreatifitas rendah lebih tinggi dibandingkan dengan ratarata hasil belajar TIK siswa dengan multimedia pembelajaran interaktif macromedia flash berdasarkan kreatifitas rendah.

Hasil pengujian lanjut di atas, menunjukkan adanya interaksi antara multimedia pembelajaran interaktif dan kreatifitas terhadap hasil belajar TIK. Interaksi multimedia pembelajaran interaktif dan kreatifitas dapat ditunjukkan seperti pada Gambar 1 berikut ini: 


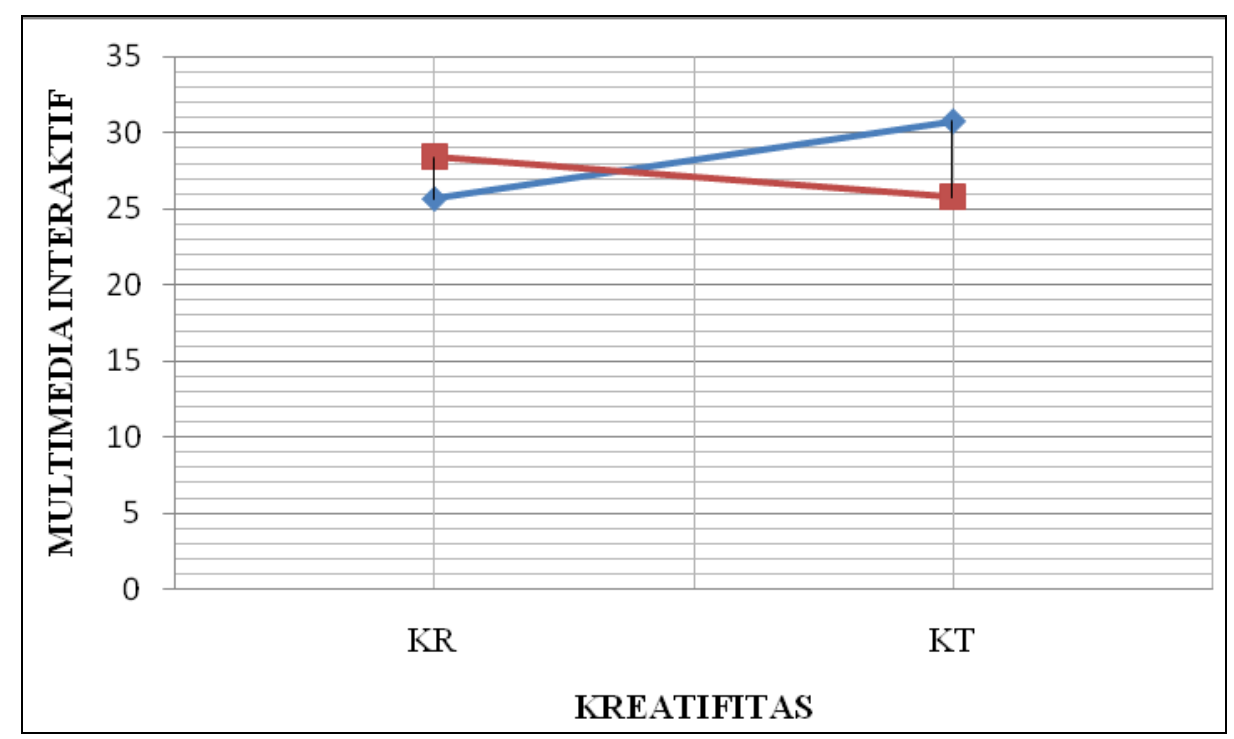

Gambar 1. Interaksi Antara Multimedia Pembelajaran Interaktif Dan Kreatifitas

Berdasarkan hasil pengujian hipotesis ketiga yang menyatakan adanya interaksi antara multimedia pembelajaran interaktif dengan kreatifitas, maka perlu dilakukan uji perbedaan rata-rata antara dua proposi. Gambar 1 menunjukkan pengaruh dan interaksi dari multimedia pembelajaran interaktif dan kreatifitas terhadap hasil belajar TIK yang diperoleh siswa, rata rata hasil belajar TIK yang dibelajarkan dengan multimedia pembelajaran interaktif macromedia flash lebih tinggi dibandingkan dengan multimedia pembelajaran interaktif power point. Penelitian ini juga membuktikan factor kreatifitas sebagai salah satu karakteristik siswa perlu diperhatikan karena terbukti bahwa kreatifitas berpengaruh terhadap hasil belajar TIK.

\section{Pembahasan}

Perbedaan Hasil Belajar TIK Antara

Siswa Yang Dibelajarkan Dengan Menggunakan Multimedia Pembelajaran Interaktif Macromedia Flash Dan Siswa Yang Dibelajarkan Dengan Menggunakan Multimedia Pembelajaran Interaktif Power Point. Dari hasil pengolahan data yang dilakukan terdapat perbedaan hasil belajar TIK antara siswa yang dibelajarkan dengan multimedia pembelajaran interaktif macromedia flash dan siswa yang dibelajarkan dengan multimedia pembelajaran interaktif power point yaitu rata-rata hasil belajar TIK siswa yang belajarkan dengan menggunakan multimedia pembelajaran interaktif macromedia flash lebih tinggi dibandingkan dengan siswa yang dibelajarkan dengan menggunakan multimedia pembelajaran interaktif power point. Kenyataan ini membuktikan bahwa penggunaan multimedia pembelajaran interaktif macromedia flash lebih baik dalam meningkatkan pengetahuan siswa dalam pembelajaran TIK daripada penggunaan multimedia pembelajaran interaktif power point.

Smaldino et al. (2005:148) menjabarkan media interaktif berbasis komputer menciptakan pembelajaran multimedia yang menggabungkan antara video dan computer-assisted instruction. Hal tersebut merupakan sistem penyampaian pembelajaran berupa rekaman visual, suara dan bahan-bahan berupa video yang diperkenalkan diabwah kendali komputer dan bukan hanya dapat dilihat dan didengar, tetapi siswa juga dapat memberi tanggapan (active response) dengan demikian tanggapan atau interaksi siswa mempengaruhi urutan penyajian materi (sequence of the presentation). Smaldino et al. (2005) meneruskan bahwa kelebihan media interaktif yaitu; (1) memanfaatkan media ganda (multiple media) - text, audio, grafik, gambar dan video, semuanya dapat disatukan dalam penyampaian materi pembelajaran; (2) partisipasi pembelajar (learner participation) - model dengan bahan-bahan video yang interaktif memerlukan interaksi siswa dalam aktivitas pembelajaran, materi membantu ke 
arah pembentukan perhatian para siswa dan mereka diikutsertakan atau berinteraksi lebih besar dalam pembelajaran dibandingkan dengan mangamati gambar saja; (3) individu (individualization) - dengan adanya kesempatan bagi siswa untuk mengulang; (4) fleksibilitas (flexibility) - siswa dapat memilih apa yang akan dipelajarinya dari menu, memilih bagian-bagian yang secara logika paling tepat untuk menjawab pertanyaan; (5) simulasi (simulation) - video interaktif dapat memberikan pengalaman simulasi seperti medicine, machine operations and expecially interpersonal skills.

Macromedia Flash merupakan sebuah program aplikasi standar authoring tool profesional yang digunakan untuk membuat animasi vektor dan bitmap yang sangat menakjubkan untuk membuat suatu situs interaktif, menarik dan dinamis (Andreas, 2003). Software ini berbasis animasi vektor yang dapat digunakan untuk menghasilkan animasi web, presentasi, game, film maupun $\mathrm{CD}$ interaktif, dan $\mathrm{CD}$ pembelajaran. Program ini juga dapat diisi dengan bitmap yang diimpor dari program lain. Salah satu keunggulan dari Macromedia Flash adalah ukurannya yang begitu kecil namun dapat menampilkan animasi web yang mengagumkan. Flash juga mempunyai kemampuan untuk membuat animasi secara Streaming, yaitu dapat menampilkan animasi langsung meskipun proses download dan loading belum selesai seluruhnya. Selain itu dengan Flash juga dapat dibuat movie kartun dan aplikasi web interaktif yang memungkinkan pengguna dapat berinteraksi langsung dengan aplikasi yang dibuatnya.

$$
\text { Pengguanaan multimedia }
$$

pembelajaran interaktif macromedia flash dalam pembelajaran TIK memungkinkan siswa untuk berinteraksi langsung dan melakukan kontrol langsung pada sumber informasi sehingga memungkinkan siswa untuk langsung menemukan informasiinformasi yang sedang dipelajari. Pembelajaran dengan multimedia pembelajaran interaktif macromedia flash memungkinkan guru bebas melakukan interaksi dengan siswa sehingga pembelajaran bersifat interaktif yang membuat pembelajaran terfokus pada informasi yang sedang dipelajari. Pada pembelajaran ini guru mengacu pada penyajian informasi akademik yang baru yang penyampaiannya dapat dihentikan pada setiap urutan-urutan (sekuensi) yang dikehendaki sehingga siswa tidak mengalami banyak kesulitan untuk mengikuti proses pembelajaran dan siswa dapat mengulang sejenak suatu informasi yang kurang dipahami. Pembelajaran dengan menggunakan multimedia pembelajaran interaktif macromedia flash lebih mengutamakan variasi teknik penyajian yang menarik yaitu dengan menggabungkan penggunaan media audio, visual dan animasi sehingga penyampaian informasi menarik dan memberikan kesempatan kepada siswa untuk aktif dan kreatif yang dapat berpengaruh positif dalam mengingkatkan hasil belajar TIK siswa.

Sementara pada proses dengan menggunakan multimedia pembelajaran interaktif power point siswa tidak berinteraksi atau melakukan kontrol langsung langsung pada sumber informasi dan pembelajaran didominasi oleh guru dengan menyajikan informasi secara linier.

Menurut Widada (2010) Multimedia interaktif Power point merupakan salah satu program Multimedia audio visual yang berbentuk aplikasi dari program komputer, yang digunakan sebagai alat bantu untuk memaparkan atau mempresentasikan sebuah materi tertentu. Aplikasi ini biasa dipakai oleh dunia bisnis, akademis, pelatihan dan lainnya. Power point merupakan sebuah software yang dibuat dan dikembangkan oleh perusahaan microsoft, dan merupakan salah satu program berbasis Multimedia. Didalam komputer, biasanya program ini sudah dikelompokkan dalam program microsoft office. Program ini dirancang khusus untuk menyampaikan presentasi, baik yang diselenggarakan oleh perusahaan, pemerintah, pendidikan maupun perorangan dengan berbagai fitur menu yang mampu menjadikannya sebagai Multimedia komunikasi yang menarik.

Pada proses penyajiannya dapat dihentikan pada setiap urutan-urutan (sekuensi) yang dikehendaki siswa namun tampilan dari informasi yang disampaikan realistis karena didominasi oleh informasi. Secara ringkas dapat dinyatakan bahwa teknik penyajian informasi kurang bervariasi dibandingkan dengan penggunaan multimedia pembelajaran interaktif macromedia flash. Pembelajaran dengan menggunakan multimedia pembelajaran interaktif power point menempatkan guru menggunakan kontrol pembelajaran dengan aktif, sementara siswa relatif pasif menerima dan mengikuti 
apa yang disampaikan guru. Guru menyampaikan materi secara terstruktur dengan harapan materi pelajaran yang disampaikan dapat dikuasai dengan baik dengan terfokus kepada kemampuan akademik.

Meskipun dalam penelitian diperoleh data bahwa hasil belajar TIK siswa lebih tinggi jika dibelajarkan dengan multimedia pembelajaran interaktif macromedia flash daripada hasil belajar TIK siswa yang dibelajarkan dengan multimedia pembelajaran interaktif power point, namun dalam pelaksanaannya kedua multimedia pembelajaran ini secara umum telah mampu meningkatkan pemahaman dan hasil belajar TIK siswa. Dengan demikian dapat disimpulkan bahwa hasil belajar TIK siswa yang dibelajarkan dengan menggunakan multimedia pembelajaran interaktif macromedia flash lebih tinggi dibandingkan dengan hasil belajar TIK siswa yang dibelajarkan dengan menggunakan multimedia pembelajaran interaktif power point.

Perbedaan Hasil Belajar TIK Antara Siswa Yang Memiliki Kreatifitas Tinggi Dan Siswa Yang Memiliki Kreatifitas Rendah. Hasil penelitian menunjukkan bahwa rata-rata hasil belajar TIK siswa yang memiliki kreatifitas tinggi lebih tinggi daripada hasil belajar TIK siswa yang memiliki kreatifitas rendah. Hal ini mengindikasikan bahwa siswa yang memiliki kreatifitas tinggi lebih mampu memahami pelajaran TIK dibandingkan dengan siswa yang memiliki kreatifitas rendah. Siswa yang memiliki kreatifitas Tinggi memiliki ciri berfikir kreatif adalah ciri non aptitude, juga siswa yang memiliki kreativitas tinggi berarti mempunyai kemampuan dalam penyelesaian masalah, aktif dan berusaha menemukan jawaban yang tepat dari suatu permasalahan. Sedangkan siswa yang memiliki kreativitas rendah rendah hanya sebatas penyelesaian masalah dan pasif. Dengan demikian dapat diduga bahwa hasil belajar siswa yang memiliki kreativitas ltinggi akan lebih tinggi dari siswa yang memiliki kreativitas rendah.

Kreativitas adalah kegiatan yang mendatangkan hasil yang sifatnya baru, berguna dan dapat dimengerti (Campbell, 1986). Senada dengan pendapat dari Utami Munandar (2009:12) mengatakan bahwa kreativitas adalah hasil dari interaksi antar individu dan lingkungannya. Seseorang mempengaruhi dan dipengaruhi oleh lingkungan dimana ia berada, dengan demikian baik perubah di dalam individu maupun didalam lingkungan dapat menunjang atau dapat menghambat upaya kreatif. Implikasinya adalah bahwa kemampuan kreatif dapat ditingkatkan melalui pendidikan. Kreativitas dapat pula ditinjau dari kondisi pribadi dan lingkungan yang mendorong (press) individu ke prilaku aktif.

Defenisi Pribadi bahwa kreativitas merupakan titik pertemuan yang khas antara tiga atribut psikologist, intelegensi, gaya kognitif, dan kepribadian/ motivasi. Bersamasama ketiga segi dari alam pikiran ini membantu memahami apa yang melatarbelakangi individu yang kreatif. Dimensi kepribadian/ motivasi meliputi ciriciri seperti fleksibilitas, toleransi terhadap kedwiartian, dorongan untuk berprestasi dan mendapat pengakuan, keuletan dalam menghadapi rintangan dan pengambilan resiko yang moderat. Definisi Proses meliputi seluruh proses kreatif dan ilmiah mulai dari menemukan masalah sampai dengan menyampaikan hasil dengan langkah-langkah meliputi tahap persiapan, inkubasi, iliuminasi, dan verifikasi. Defenisi Produk adalah defenisi kreativitas yang berpusat pada hasil tindakan kreatif yang menekankan unsur orisinalitas, kebaruan dan kebermaknaan. Defenisi Press bahwa kreativitas adalah bentuk inisiatif yang ditampakkan oleh adanya kekuatan untuk melepaskan diri dari alur berpikir yang biasa.

Munandar (Danim 2010:136) mengemukakan ciri-ciri kreativitas seperti sebagai berikut: senang mencari pengalaman baru, memiliki keasyikan dalam mengerjakan tugas-tugas yang sulit, memiliki inisiatif, memiliki ketekunan yang tinggi, cenderung kritis terhadap orang lain, berani menyatakan pendapat dengan keyakinannya, selalu ingin tahu, peka atau perasa, enerjik dan ulet, menyukai tugas-tugas yang majemuk, percaya kepada diri sendiri, mempunyai rasa humor, memiliki rasa keindahan, dan berwawasan masa depan dan penuh imajinasi.

Dalam rangka membangun kemampuan dan kualitas kreativitas yang optimal, siswa harus mampu memanfaatkan sumber belajar yang ada secara maksimal dan efisien. Kreativitas belajar mempengaruhi proses belajar seseorang, dengan kata lain kreativitas juga mempengaruhi hasil belajar seseorang. Oleh karena itu, jika siswa 
memiliki kreativitas yang tinggi, maka siswa itu dapat diduga akan mempunyai prestasi yang tinggi juga.

Dengan demikian kreativitas berhubungan dengan keaktifan dalam belajar. Jika kreativitas tinggi, maka siswa cenderung lebih menguasai materi pelajaran dan jika diuji tentu akan memperoleh hasil belajar yang tinggi, sebaliknya jika kreativitasnya rendah hasil belajarnya cenderung rendah, dengan demikian kreativitas siswa perlu dibangkitkan dalam setiap kegiatan pembelajaran untuk meningkatkan hasil belajar.

Interaksi Antara Multimedia Pembelajaran Interaktif dan Kreatifitas Terhadap Hasil Belajar TIK. Temuan penelitian menunjukkan bahwa terdapat interaksi antara multimedia pembelajaran dan kreatifitas terhadap hasil belajar TIK. Siswa yang memiliki kreatifitas tinggi yang dibelajarkan dengan multimedia interaktif Macromedia flash memperoleh hasil belajar TIK yang lebih tinggi daripada siswa yang memiliki kreatifitas tinggi yang dibelajarkan dengan menggunakan multimedia interaktif power point. Demikian pula siswa yang memiliki kreatifitas rendah yang dibelajarkan dengan menggunakan multimedia interaktif Macromedia Flash memperoleh hasil belajar TIK yang lebih rendah dibandingkan dengan siswa yang dibelajarkan dengan menggunakan multimedia interaktif power point. Walaupun dalam penelitian ini tidak terdapat perbedaan yang signifikan. Hal ini mengindikasikan adanya interaksi antara penggunaan multimedia interaktif pembelajaran dengan kreatifitas terhadap hasil belajar TIK siswa.

Multimedia Interaktif Power Point merupakan salah satu program Multimedia audio visual yang berbentuk aplikasi dari program komputer, yang digunakan sebagai alat bantu untuk memaparkan atau mempresentasikan sebuah materi tertentu. Aplikasi ini biasa dipakai oleh dunia bisnis, akademis, pelatihan dan lainnya. Power point merupakan sebuah software yang dibuat dan dikembangkan oleh perusahaan microsoft, dan merupakan salah satu program berbasis Multimedia. Pada prinsipnya program ini terdiri dari beberapa unsur rupa dan pengontrolan operasionalnya. Unsur rupa yang dimaksud terdiri dari slide, teks, gambar dan bidang-bidang warna yang dapat dikombinasikan dengan latar belakang yang tersedia. Unsur rupa tersebut dapat dibuat tanpa gerak atau dibuat dengan gerakan tertentu sesuai dengan keinginan. Seluruh tampilan dari program ini dapat kita atur sesuai keperluan, apakah dapat berjalan sendiri sesuai dengan timing yang kita inginkan atau berjalan secara manual yaitu dengan mengklik tombol mouse. Biasanya jika digunakan untuk penyampaian bahan ajar yang mementingkan terjadinya interaksi antara siswa dengan guru, maka control operasinya menggunakan cara manual.

Pembelajaran dengan menggunakan multimedia interaktif Macromedia Flash hakikatnya berorientasi pada guru dengan materi yang disajikan dikemas dalam bentuk tanyangan (slide) yang bersifat linier sehingga lebih cocok bagi siswa yang memiliki kreatifitas rendah, hal ini disebabkan siswa yang memilki kreatifitas cenderung pasif menunggu bimbingan dari guru. Dengan demikian guru memiliki banyak kesempatan untuk memberikan motivasi, semangat dan arahan sehingga siswa lebih termotivasi dan terdorong dalam mengetahui dan memahami informasi penerapan teknologi informasi dan komunikasi dalam kehidupan sehari-hari dan meningkatkan hasil belajarnya. Akan tetapi jika pembelajaran multimedia interaktif Power Point diberikan kepada siswa yang memiliki kecerdasan tinggi akan menimbulkan kebosanan dan kejenuhan. Hal ini disebabkan proses pembelajaran terkesan monoton dan kurang memiliki variasi dalam penyajiannya serta pembelajaran kurang memberikan kesempatan kepada siswa untuk aktif dan imajinatif.

Mayer (2009) mengatakan pembelajaran menggunakan multimedia adalah pembelajaran yang disajikan melalui kata-kata dan gambar yang bertujuan untuk mempromosikan pembelajaran siswa yang dibelajarkan dengan cara ini akan mendapatkan pemahaman yang lebih baik daripada disajikan hanya dengan kata-kata saja. Dari defenisi ini nampak adanya kesamaan bahwa teknologi multimedia merangkumi berbagai media dalam satu software pembelajaran yang interaktif.

Kreativitas sebagai suatu proses, pada prinsipnya hampir sama dengan langkah metode ilmiah, menurut Torrance (1974) meliputi proses merasakan adanya permasalahan, kesenjangan informasi, ketidaklengkapan unsur dan sesuatu yang ditanyakan, proses membuat terkaan dan merumuskan hipotesis, proses mengevaluasi 
dan menguji hipotesis, proses meninjau ulang dan menguji kembali, serta akhirnya mengkomunikasikan kesimpulan yang diperoleh.

Kreativitas memiliki peranan yang penting dalam kehidupan manusia. Dengan kreativitas yang dimilikinya, manusia memberi bobot dan makna dalam kehidupannya. Menurut Semiawan (1997:80) kreativitas dapat dibedakan menjadi kreativitas personal dan kreativitas kebudayaan. Kreativitas personal adalah kemampuan yang dimiliki oleh siapapun sedangkan kreativitas kebudayaan terekspresikan dalam suatu penemuan yang secara signifikan bermakna bagi masa depan kemanusiaan.

Multimedia interaktif merupakan multimedia interakstif pembelajaran yang menuntut adanya interaksi langsung dengan sumber informasi sehingga dapat meningkatkan rasa keingin tahuan, minat, dan, motivasi belajar bagi siswa yang memiliki kreatifitas tinggi. Sejalan dengan itu bagi siswa yang memiliki kreatifitas tinggi akan terpacu untuk lebih giat belajar dan mampu mengendalian diri karena mereka selalu optimis untuk dapat mengetahui informasi tentang tujuan penerapan TIK dalam kehidupan sehari hari dan meningkatkan hasil belajarnya. Sedangkan siswa yang memilki kreatifitas rendah mungkin akan merasa khawatir dan was-was kalau mereka tidak mampu mengikuti pembelajaran. Hal ini terjadi karena karakteristik kreatifitas rendah adalah siswa senderung hanya sebatas penyelesaian masalah dan pasif, kurangnya percaya diri akibat tidak tidak mampu mengubah keadaan yang buruk. Siswa yang memiliki kreatifitas rendah juga kurang mampu mengendalikan diri dan menangkap sinyal-sinyal sosial yang mengisiaratkan apa yang dikehendaki oleh orang lain sehingga dalam komunikasi dengan guru dalam pembelajaran tidak terjadi dengan baik yang berakibat dapat kurang efektif jika jika dibelajarkan dengan menggunakan multimedia interaktif Macromedia Flash.

Dengan dimikian hasil belajar TIK siswa yang memiliki kreatifitas rendah lebih tinggi dibandingkan dengan siswa yang memiliki kreatifitas tinggi jika dibelajarkan dengan menggunakan multimedia interaktif Power point. Dengan demikian pembelajaran multimedia interaktif Macromedia Flash lebih tepat dibelajarakan kepada siswa yang memiliki kreatifitas tinggi dan pemberlajaran dengan menggunakan multimedia interaktif Power Point lebih tepat diberikan kepada siswa yang memiliki kreatifitas rendah.

\section{PENUTUP \\ Simpulan}

Berdasarkan pengolahan data dan pembahasan terhadap hasil penelitian yang dikemukakan sebelumnya maka dalam penelitian ini dapat disimpulkan bahwa :

1. Hasil belajar TIK siswa yang dibelajarkan dengan menggunakan multimedia pembelajaran interaktif Macromedia Flash lebih tinggi dari hasil belajar TIK siswa yang dibelajarkan dengan menggunakan multimedia pembelajaran interaktif Power Point.

2. Hasil belajar TIK siswa yang memiliki Kreativitas tinggi lebih tinggi daripada hasil belajar TIK siswa yang memiliki Kreativitas rendah.

3. Terdapat interaksi antara penggunaan multimedia dan Kreativitas dalam mempengaruhi hasil belajar TIK siswa. Dari hasil pengujian lanjut ternyata siswa yang memiliki Kreativitas tinggi memperoleh hasil belajar TIK lebih tinggi jika dibelajarkan dengan menggunakan multimedia pembelajaran interaktif Macromedia Flash daripada multimedia pembelajaran interaktif Power Point, sedangkan siswa yang memilki Kreativitas rendah lebih tinggi hasil belajarnya jika dibelajarkan dengan multimedia pembelajaran interaktif Power Point daripada multimedia pembelajaran interaktif Macromedia Flash.

\section{Saran}

Berdasarkan simpulan dan implikasi seperti yang telah dikemukakan maka disarankan beberapa hal sebagai berikut :

1. Dalam upaya peningkatan hasil belajar TIK, maka guru yang mengasuh mata pelajaran TIK disarankan agar menggunakan multimedia pembelajaran yang tepat dalam menyajikan konsekonsep dan penerapan TIK dalam kehidupan sehari-hari.

2. Disarankan kepada guru agar memperhatikan tingkat Kreativitas yang yang dimiliki siswa dan mengelompokkan mereka berdasarkan tingkat Kreativitasnya, yakni Kreativitas rendah dan Kreativitas tinggi. 
3. Disarankan kepada pihak pengambil kebijakan dilingkungan SMA Negeri 1 Hamparan Perak untuk mengadakan pelatihan cara mengidentifikasi dan mengukur tingkat Kreativitas siswa bagi guru-guru agar guru-guru memiliki keterampilan mengelompokkan tingkat Kreativitas siswa.

4. Disarankan kepada pihak pengambil kebijakan dilingkungan SMA Negeri 1 Hamparan Perak untuk mengadakan pelatihan cara membuat multimedia pembelajaran interaktif Macromedia Flash dan multimedia pembelajaran interaktif Power Point yang tepat untuk pembelajaran TIK.

5. Guna penelitian lebih lanjut pada penggunaan multimedia disamping guru yang menjadi mitra peneliti, perlu untuk disosialisasikan terlebih dahulu kepada siswa bagaimana prosedur penggunaan multimedia pembelajaran sehingga peggunaan waktu bisa seefisien mungkin serta efektifitas pembelajaran dapat tercapai.

\section{DAFTAR PUSTAKA}

Anderson, C. (2001). Taxonomy of Educational Objectives. New York: Logman

Andreas S (2003). Menguasai Pembuatan Animasi dengan Flash MX. Jakarta, PT Elex Multimedia Komputindo.

Arikunto, S. (2002). Dasar-dasar Evaluasi Pendidikan. Jakarta: Bumi Aksara.

Contains information and resources for Macromedia Flash Player. Macromedia Flash

MX.

http://www.macroMultimedia.com/supp ort/flash/, diakses 17 februari 2012.

Departemen Pendidikan Nasional (2003). Kurikulum Teknologi Informasi dan Komunikasi (TIK). Jakarta: Departemen Pendidikan Nasional.

Didik, W., (2003). Tips dan Trik Macromedia Flash MX 5 dengan ActionScript. Jakarta. PT Elex Multimedia Komputindo.

Djamarah, S,B. Dan Zain, A. (2002). Strategi Belajar Mengajar. Jakarta: Rhineka Cipta.

Gagne,R.M.\&Briggs,L.J. (1979). Principles of Instructional Design, Second Edition. New York. Holt, Rinehart and Winston.
Gagne, R.M, (1985). The Condition of Learning, Third edition, New York: Holt, Rinehart and Winston.

Heinich, Molenda 7 Russell (1985). Instructional Media and The New Technologiesn of Instructiona Canada: John Wiley 7 Sons, Inc.

HR, Widada. (2010). Mudah Membuat Media Pembelajaran Multimedia Interaktif Untuk Guru Dan Profesional. Yogyakarta : Pustaka Widyatama.

Kadir A. Triwahyuni T. (2003). Pengenalan Teknologi Informasi. Jogjakarta: Andi.

Khoiru Iif, dkk. (2011). Strategi Pembelajaran Sekolah Terpadu. Pengaruhnya Terhadap Konsep Pembelajaran Sekolah Swasta dan Negri. Jakarta: PT. Prestasi Pustakaraya.

Kunandar (2007). Guru Profesional : Implementasi Kurikulum Tingkat Satuan Pendidikan (KTSP) dan Sukses dalam Sertifikasi Guru (Edisi Revisi). Jakarta: Rajawali Press.

Mayer, Richard, E. (2009). Multimedia Learning (second edition). United State of America: Camridge University Press.

Miarso Yusufhadi, (2004). Menyemai Benih Teknologi Pendidikan. Jakarta: Kencana.

Mudjiono, Dimyati, (1999). Belajar dan Pembelajaran. Jakarta: Rhineka Cipta.

Munandar Utami. (2009). Pengembangan Kreativitas Anak Berbakat. Jakarta: Rhineka Cipta.

Munir (2008). Kurikulum Berbasis Teknologi Informasi dan Komunikasi. Bandung : Penerbit Alphabeta.

Murni, Sylviana. (2008). Pemanfaatan ICT dalam Pendidikan. Jakarta: Makalah Seminar Nasional The Power of ICT in Education, PPs UNJ, 15 April 2008.

Reigeluth, C. M. (1983). Instructional-Design Theories And Models: An Overview of Their Current Status. London : Lawrence Erlbaum Associates Publisher.

Romizowski, A.J. (1993). Developing Interactive Multimedia Courseware and Networks: some curent.

Sadiman, A. S, Raharjo, Haryono A, Rahardito. (2003) Media Pendidikan, Pengertian, Pengembangan dan Pemanfaatannya. Jakarta: Rajawali Pers. 
Semiawan, Conny., (1997). Perspektif Pendidikan Anak Berbakat., Jakarta: Grasindo.

Smaldino, Russel, Heinich \& Molenda. (2005). Instructional Technology and Multimedia For Learning. New Jersey: Person Education, Inc.

Snelbecker, E. G. (1974). Learning Theory, Instructional Theory and Psychoeducational design, New York; Mc Graw Hill.

Sudarwan, D., (2010). Perkembangan Peserta Didik. Bandung: Alfabeta.

Sudjana, N. (2001). Cara Belajar Siswa Aktif Dalam Proses Belajar Mengajar. Bandung: Sinar Baru Algensindo.

Suparman. A.(2001). Desain Instruksional. Jakarta:P2T-UT Dikti Depdikbud

Supriadi. (1999). Kreativitas Kebudayaan dan Perkembangan IPTEK. Bandung: CV Alpa Beta.
Trianto. (2010). Mendesain Model Pembelajaran Inovatif-Progresif. Jakarta: Kencana.

Uno, H.B. (2008). Orientasi Baru Dalam Psikologi Pembelajaran. Jakarta: Bumi Aksara.

Warsita, B., (2008). Teknologi Pembelajaran. Landasan dan Aplikasinya. Jakarta: Rineka Cipta.

Wena, M. (2009). Strategi Pembelajaran Inovatif Kontemporer Suatu Tinjauan Konseptual Operasional. Jakarta : Gramedia.

Woolfolk. A.E. (2009). Educational Psychology Active Learning Edition. Bagian pertama dan kedua. Alih bahasa: Helly Prajitno Soetjipto dan Sri Mulyanti Soetjipto. Yogyakarta: Pustaka Belajar. 